\title{
DETEKSI GEN-GEN PENYANDI FAKTOR VIRULENSI PADA BAKTERI VIBRIO
}

\author{
Ince Ayu Khairani Kadriah"), Endang Susianingsih"), Sukenda"*), \\ Munti Yuhana"*), dan Enang Harris"*) \\ *) Balai Riset Perikanan Budidaya Air Payau \\ Jl. Makmur Daeng Sitakka No. 129, Maros 90512, Sulawesi Selatan \\ E-mail: e_sisy@yahoo.com \\ **) Departemen Budidaya Perairan-FPIK, Institut Pertanian Bogor \\ Jl. Lingkar Akademik, Kampus IPB Darmaga, Bogor 16680
}

(Naskah diterima: 21 Januari 2011; Disetujui publikasi: 5 April 2011)

\begin{abstract}
ABSTRAK
Penelitian untuk mendeteksi gen-gen penyandi virulensi dilakukan dengan menggunakan isolat bakteri yang diisolasi dari budidaya udang windu di berbagai daerah di Sulawesi Selatan dan Jawa. Pada penelitian ini digunakan primer spesifik untuk mendeteksi gen-gen virulen toxR gene, hemolysin ( $v v h)$ gene, dan GyrB gene dengan metode PCR. Dari 35 isolat yang diisolasi, 20 isolat terdeteksi memiliki gen virulensi dan 8 di antaranya memiliki dua gen virulen. Spesies bakteri yang memiliki gen virulen adalah: V.harveyi, $V$. parahaemolyticus, V. mimicus, dan V. campbelli.
\end{abstract}

KATA KUNCl: vibrio, faktor virulen, primer spesifik

ABSTRACT: Detection of vibrio virulence factor genes. By: Ince Ayu Khairani Kadriah, Endang Susianingsih, Sukenda, Munti Yuhana, and Enang Harris

Research to identifiy genes which encodes virulence factors involved in pathogenicity to tiger shrimp was done using bacteria isolates from South Sulawesi dan Jawa. Of 35 bacteria isolates, 20 isolates were detected to have virulence genes of which 8 of them have virulent genes. Three pairs of the specific primer set (toxR gene, hemolysin (vvh) gene dan GyrB gene), could amplify the expected gene fragment in PCR using templates from all 20 studied bacteria isolates. Genes which encodes a virulence factor were detected from V. harveyi, V. parahaemolyticus, V. mimicus, and V. campbelli.

KEYWORDS: vibrio, virulence factor, specific primer

\section{PENDAHULUAN}

Di antara beberapa bakteri patogen, spesies vibrio sudah dikenal sebagai penyebab penyakit vibriosis pada udang penaeid. Bakteri vibrio adalah salah satu penyebab penyakit yang cukup banyak menyerang hewan budidaya seperti udang windu (Karunasagar et al., 1994), beberapa spesies ikan dan kekerangan (Austin \& Zhang,
2006) bahkan juga karang (Ben-Haim et al., 2003). Beberapa spesies Vibrio berpendar seperti Vibrio cholerae (biotype albensis), $V$. fischeri, V. harveyi, V. logei, V. splendidus, V. mediterranei (Farmer \& Hickman-Brenner, 1992), V. orientalis (Yang et al., 1983), Photobacterium leiognathi dan P. Phosphoreum diketahui berhubungan erat dengan beberapa kejadian penyakit pada pembenihan dan pembesaran hewan budidaya. Pada banyak 
kejadian penyakit pada budidaya udang windu, V. harveyi selalu ditemukan (LavillaPitogo et al., 1990, 1998; Karunasagar et al., 1994; Austin \& Zhang, 2006; Cano-Gomez, 2009).

Kejadian penyakit di lapangan selalu ditandai dengan terjadinya fenomena udang dan air bercahaya (bioluminescence). Selain itu, udang juga terlihat lemah dalam pergerakannya dan mengalami nekrosis (Karunasagar, 1994). Leano (1998) menyatakan bahwa pada saat udang telah mengalami gejala-gejala klinis seperti yang disebutkan maka konsentrasi bakteri vibrio pada hepatopankreas sudah mencapai kepadatan $10^{5}-10^{6} \mathrm{CFU} / \mathrm{mL}$. Kepadatan di atas atau sama dengan $10^{5} \mathrm{CFU} /$ $\mathrm{mL}$ menurut Leano (1998), kepadatan yang cukup untuk menjadikan bakteri vibrio bersifat patogen di alam. Hal inilah yang menjadi alasan sulitnya untuk melakukan upaya pencegahan penyakit jika berdasarkan munculnya gejala klinis di lapangan karena kepadatan bakteri sudah tinggi.

Adanya metode deteksi dini yang menggunakan penanda spesifik dapat dengan cepat mendeteksi adanya kontaminasi bakteri Vibrio harveyi akan sangat membantu dalam penanganan dan pencegahan awal yang tepat waktu untuk mengurangi kematian udang. Disebabkan begitu dekatnya kekerabatan antara $V$. harveyi dengan beberapa spesies vibrio lain seperti $V$. parahaemolyticus, $V$. alginolyticus, V. Campbellii, dan V. carchariae (Kita-Tsukamoto et al.,1993), maka identifikasi V. harveyi dengan metode biokimia tidak akurat lagi (Conejero \& Hedreyda, 2004). Oleh karena itu, metode PCR yang dapat menunjukkan sekuen nukleotida secara spesifik untuk satu jenis spesis bakteri dapat menjadi metode deteksi yang lebih akurat dan cepat.

Tujuan dari penelitian ini adalah untuk mendeteksi keberadaan gen spesifik dari bakteri Vibrio sp. untuk selanjutnya akan digunakan sebagi penanda molekular dalam diagnosis cepat penyakit vibriosis berpendar (kunang-kunang) pada budidaya udang. Gen spesifik yang akan dideteksi pada penelitian ini adalah gen toxR (Pang et al., 2005), gene Vhh hemolysin (Conejero \& Hedreyda, 2004), dan gene GyrB (Thaithongnum et al., 2006).

Hasil dari penelitian ini selanjutnya diharapkan dapat menjadi acuan untuk pembuatan penanda molekuler spesifik yang akan digunakan dalam deteksi dini serangan penyakit vibriosis pada budidaya udang windu. Metode deteksi ini dapat digunakan untuk studi epidemiologi dan monitoring kejadian penyakit sehingga dapat dilakukan tindakan pencegahan yang tepat waktu dan tepat sasaran untuk menekan perkembangan bakteri $V$. harveyi virulen dalam media budidaya.

\section{METODOLOGI}

\section{Isolasi dan Identifikasi Bakteri Vibrio dari Tambak Udang}

Sebelum dilakukan uji karakterisasi morfologi dan fisiologi bakteri, terlebih dahulu dilakukan isolasi koloni bakteri berpendar dari kejadian penyakit di tambak udang. Sebanyak 35 isolat bakteri diisolasi dari berbagai daerah di Sulawesi (Maros, Takalar, dan Pinrang) dan Jawa (Banyuwangi, Negara, dan Gondol-Bali) (Tabel 1). Bakteri diisolasi dari air tambak, sedimen tambak dan udang sakit. Sampel air diambil dengan menggunakan botol steril kemudian dibawa ke laboratorium. Sedangkan sampel sedimen diambil menggunakan sudip steril dan dibawa ke laboratorium menggunakan botol steril. Isolasi bakteri dilakukan dengan cara mengambil $1 \mathrm{~mL}$ air sampel dan $1 \mathrm{~g}$ sedimen tambak kemudian diencerkan secara bertingkat dalam larutan fisiologis (Benson, 1985) dan dikultur pada media TCBSA (Thiosulfat Citrate Bile Sucrose Agar) (Difco;89 gr/L) pada suhu $28^{\circ} \mathrm{C}$.

Seleksi awal isolat bakteri dilakukan berdasarkan pertumbuhan dan kemampuan pendarannya. Isolat terpilih kemudian diuji karakterisasi dan morfologinya untuk identifikasi spesies menggunakan uji biokimia. Uji biokimia ini dilakukan berdasarkan metode yang dilakukan oleh Austin (1991); Austin \& Austin (1993); Alsina \& Blanch (1994); Baumann et al. (1994); Muir (1996a). Untuk menentukan spesies dari bakteri vibrio, data hasil uji biokimia yang diperoleh diolah dengan menggunakan perangkat lunak Fortran Computer Program (Muir, 1996b). Dari hasil uji biokomia diperoleh beberapa spesies bakteri vibrio (Tabel 1). Isolat bakteri Vibrio harveyi yang diperoleh diremajakan secara berkala dengan menumbuhkannya pada media agar TCBS. Selanjutnya bakteri hasil isolasi diuji patogenisitasnya. Uji patogenisitas ini dimaksudkan untuk mendapatkan kandidat isolat bakteri yang berpotensi memiliki gen virulen. Gen virulen yang teridentifikasi selanjutnya akan digunakan sebagai penanda molekuler dalam deteksi cepat. 
Tabel 1. Isolat bakteri yang digunakan dalam penelitian

Table 1. Bacteria isolates used in the study

\begin{tabular}{|c|c|c|}
\hline $\begin{array}{l}\text { Kode bakteri } \\
\text { Bacteria code }\end{array}$ & $\begin{array}{c}\text { Asal } \\
\text { Source }\end{array}$ & $\begin{array}{c}\text { Spesies } \\
\text { Species }\end{array}$ \\
\hline 1 & Bany uwangi & V. harveyi \\
\hline 2 & Negara-Bali & Vibrio sp \\
\hline 3 & Gondol-Bali & V. parahaemolyticus \\
\hline 109 & Maros & V. campbelli \\
\hline 110 & Maros & V. harveyi \\
\hline 111 & Maros & V. harveyi \\
\hline 112 & Maros & V. harveyi \\
\hline 114 & Maros & V. harveyi \\
\hline 115 & Maros & V. harveyi \\
\hline 116 & Maros & V. mimicus \\
\hline 119 & Maros & V. mimicus \\
\hline 120 & Maros & V. harveyi \\
\hline 128 & Maros & V. harveyi \\
\hline 130 & Maros & V. harveyi \\
\hline 133 & Maros & V. harveyi \\
\hline 137 & Maros & V. harveyi \\
\hline 139 & Maros & V. harveyi \\
\hline 144 & Maros & V. harveyi \\
\hline 145 & Maros & V. harveyi \\
\hline 154 & Maros & V. mimicus \\
\hline 159 & Maros & V. harveyi \\
\hline 671 & Maros & V. mimicus \\
\hline 672 & Maros & V. mimicus/harveyi \\
\hline 673 & Maros & V. harveyi \\
\hline 675 & Maros & V. harveyi \\
\hline 676 & Maros & V. harveyi \\
\hline 5575 & Maros & V. campbelli \\
\hline 5582 & Maros & V. harveyi \\
\hline 5584 & Maros & V. mimicus/harveyi \\
\hline 5585 & Maros & V. mimicus/harveyi \\
\hline 168 & Takalar & V. harveyi \\
\hline 170 & Takalar & V. harveyi \\
\hline 173 & Takalar & V. harveyi \\
\hline 275 & Pinrang & V. harveyi \\
\hline 276 & Pinrang & V. metschnikovi \\
\hline
\end{tabular}

\section{Isolasi Genom Bakteri Kandidat}

Metode yang digunakan dalam isolasi genom bakteri adalah metode phenol-chloroform. Bakteri dikultur di dalam Nutrient broth selama 4 jam kemudian dipanen dengan cara sentrifugasi. Sebanyak $1 \mathrm{~mL}$ biakan bakteri dipindahkan ke dalam tabung eppendorf steril $1,5 \mathrm{~mL}$ dan disentrifugasi (6.000 rpm; 10 menit).
Proses sentrifugasi diulang sebanyak dua kali dan kemudian dlakukan pencucian dengan larutan fisiologis juga dengan sentrifugasi. Pelet bakteri yang dihasilkan kurang lebih 50 mg kemudian dicampur dengan $500 \mu \mathrm{L}$ lysis buffer, $20 \mu \mathrm{L}$ proteinase- $\mathrm{K}$ (stok $20 \mathrm{mg} / \mathrm{mL}$ ) dan $40 \mu \mathrm{L}$ Sodium Dodecyl Sulfate (SDS) $10 \%$. Setelah itu biakan bakteri diinkubasi dalam waterbath selama 1-3 jam pada suhu $55^{\circ} \mathrm{C}$. 
Penambahan $12.5 \mu \mathrm{L}$ RNAse dilakukan sebelum biakan disimpan pada suhu ruang selama 1530 menit. Selanjutnya ditambahkan Phenol:Chloroform:Isoamyl alcohol (PCIA 25:24:1) sebanyak $500 \mu \mathrm{L}$. Tabung eppendorf divortex secara perlahan sampai homogen dan disimpan pada suhu ruang selama 10 menit. Selanjutnya disentrifugasi pada kecepatan 13.000 rpm selama 8 menit. Lapisan paling atas diambil dan dipindahkan ke tabung eppendorf baru dan dilakukan penambahan PCIA seperti sebelumnya. Setelah lapisan paling atas dipindahkan ke tabung eppendorf baru, dilakukan penambahan satu bagian larutan Chloroform: Isoamyl alcohol (CIA 24:1) dan disentrifugasi selama 4 menit dengan kecepatan $13.000 \mathrm{rpm}$. Lapisan paling atas dipindahkan ke tabung eppendorf baru dan ditambahkan dua bagian ethanol absolut dingin kemudian dicampur perlahan sampai homogen. Dilakukan sentrifugasi dengan kecepatan 6.000 rpm selama 30 menit. Cairan dibuang kemudian pellet DNA dicuci dengan $1 \mathrm{~mL}$ ethanol $70 \%$ kemudian disentrifugasi dengan kecepatan $6.000 \mathrm{rpm}$ selama 15 menit. Pellet DNA dikeringkan selama satu malam dan setelah kering ditambahkan $100 \mu \mathrm{L}$ Buffer Tris-Etilen DiaminTetra Aceticacid (EDTA) (TE) dan selanjutnya disimpan pada suhu $-20^{\circ} \mathrm{C}$ sampai digunakan.

\section{Proses PCR}

Setelah genom bakteri berhasil diisolasi (Gambar 1), proses selanjutnya adalah deteksi gen spesifik pada isolat yang kita miliki. Deteksi gen spesifik ini dilakukan dengan melakukan amplifikasi DNA menggunakan mesin thermocycler yang lebih dikenal dengan teknik Polymerase Chain Reaction (PCR).

Proses PCR untuk memperbanyak DNA melibatkan serangkaian siklus temperatur yang berulang dan masing-masing siklus terdiri atas tiga tahapan. Tahapan yang pertama adalah denaturasi cetakan DNA (DNA template) pada temperatur $94^{\circ} \mathrm{C}-96^{\circ} \mathrm{C}$, yaitu pemisahan utas ganda DNA menjadi dua utas tunggal. Sesudah itu, dilakukan penurunan temperatur pada tahap kedua sampai $45^{\circ} \mathrm{C}-60^{\circ} \mathrm{C}$ yang memungkinkan terjadinya penempelan (annealing) atau hibridisasi antara oligonukleotida primer dengan utas tunggal cetakan DNA. Tahap yang terakhir adalah tahap ekstensi atau elongasi (elongation), yaitu pemanjangan primer menjadi suatu utas DNA baru oleh enzim DNA polimerase. Temperatur pada tahap ini bergantung pada jenis DNA polimerase yang digunakan. Proses PCR dilakukan menggunakan Ready To Go (RTG) dengan primer spesifik $V$. harveyi yang sudah ada (Tabel 2) dan dilakukan optimasi pada beberapa tingkatan suhu annealing.

Terdapat perbedaan pada proses amplifikasi DNA untuk setiap primer spesifik yang digunakan. Proses ampifikasi DNA untuk primer toxR adalah sebagai berikut: Larutan master mix dibuat dengan mencampur $20 \mu \mathrm{L}$ aquadest milliQ ke dalam 1 tube RTG (GE Healthcare UK Limited Little Chalfont Buckinghamshire, UK), kemudian ditambahkan masing-masing $1 \mu \mathrm{L}$ Primer tox RR1 dan toxRF1. Setelah larutan dihomogenkan selanjutnya dimasukkan template DNA sebanyak $3 \mu \mathrm{L}$. Kondisi proses amplifikasi untuk primer spesifik toxR diatur sebanyak 30 siklus pada suhu denaturasi $94^{\circ} \mathrm{C}$ selama 1 menit, annealing $57^{\circ} \mathrm{C}$ selama 1 menit dan elongasi $72^{\circ} \mathrm{C}$ selama 1 menit serta tahap ekstra elongasi $72^{\circ} \mathrm{C}$ selama 10 menit pada mesin PCR (Applied Biosystems 2720 Thermal Cycler). Selanjutnya sebanyak $3 \mu \mathrm{L}$ produk PCR diambil untuk proses elektroforesis dalam $1 \%(\mathrm{w} / \mathrm{v}) \mathrm{gel}$ agarose. Proses amplifikasi DNA untuk primer spesifik $v v h$ gen (hemolysin) diatur sebanyak 30 siklus pada suhu denaturasi $94^{\circ} \mathrm{C}$ selama 1 menit, annealing $53^{\circ} \mathrm{C}$ selama 1 menit dan elongasi $72^{\circ} \mathrm{C}$ selama 1 menit (Conejero \& Hedreyda, 2004). Sedangkan untuk amplifikasi gen gyrB proses PCR juga diatur sebanyak 30 siklus dengan suhu denaturasi $94^{\circ} \mathrm{C}$ selama 1 menit, annealing $60^{\circ} \mathrm{C}$ selama 1 menit dan elongasi $72^{\circ} \mathrm{C}$ selama 2 menit serta tahap ekstra elongasi $72^{\circ} \mathrm{C}$ selama 7 menit (Thaithongnum et al., 2006).

\section{Elektroforesis}

Hasil PCR kemudian akan diaplikasikan pada gel agarosa untuk diobservasi dan didokumentasikan. Elektroforesis minigel hanya optimum untuk pemisahan DNA berukuran kecil (ratusan bp hingga sekitar 10 kb). Kondisi running pada minigel: Voltase 70 hingga $120 \mathrm{~V}$, waktu running: 30 hingga 120 menit. Kondisi kuat arus (Ampere) akan menyesuaikan setting Voltase sehingga tidak perlu di-setting lagi. Buffer elektroforesis diperlukan untuk menciptakan kondisi bermuatan listrik. Pada umumnya berupa buffer Tris Aceticacid EDTA (TAE) atau Tris Boric EDTA (TBE). 


\section{HASIL DAN BAHASAN}

Hasil isolasi genom menunjukkan semua bakteri berhasil diisolasi genomnya dengan baik (Gambar 1). Hasil PCR yang diperoleh menggunakan primer spesifik GyrB, menunjukkan bahwa gen spesifik GyrB dapat dideteksi pada isolat : $5582 ; 5584 ; 109 ; 120$; $5585 ; 154 ; 159 ; 672 ; 676 ; 128 ; 133 ; 137$; dan 139 (Gambar 2a dan 2b). Gen ini dapat digunakan sebagai penanda bakteri berpendar pada panjang basa $363 \mathrm{bp}$ (Thaithongnum et al., 2006). Gen GyrB mengkode protein subunit B dari DNA gyrase (topoisomerase type II). DNA gyrase mengatur superkoiling pita ganda DNA. Gen gyrB sangat diperlukan untuk replikasi DNA di mana gen ini berperan dalam pembentukan protein yang mengkode enzim Gyrase. Enzim ini terdistribusi pada hampir semua spesies dalam genus vibrio. Enzim ini yang mengurangi tekanan saat doublestranded DNA sedang tidak terikat oleh ikatan helikase hal ini menyebabkan terjadinya superkoiling DNA. Banyak antibiotik bekerja dengan menyerang gyrase. Gyrase DNA bakteri hadir di prokariota dan beberapa eukariota, tetapi enzim ini tidak sepenuhnya mirip dalam struktur atau urutan, dan memiliki kedekatan yang berbeda untuk setiap molekul yang berbeda. Enzim ini tidak ditemukan pada manusia. Hal ini membuat gyrase sebagai target yang baik untuk antibiotik. Bakteri patogen memiliki struktur gen $G y r-B$ yang spesifik dibandingkan bakteri lainnya (Thaithongnum et al., 2006).

Identifikasi gen hemolysin dengan primer spesifik vvh menunjukkan isolat yang teridentifikasi memiliki gen ini adalah: 1, 2, 3, 5582, 5584, 154, 671, 676 (Gambar 3a, 3b, dan 3c). Dari gambar ini terlihat bahwa gen penyandi sifat virulensi dengan menggunakan primer spesifik hemolysin (vhh) gen dapat teridentifikasi pada posisi $308 \mathrm{bp}$. Panjang basa dari hasil PCR ini sesuai dengan yang dilaporkan oleh Conejero \& Hedreyda (2004). Hemolysin adalah eksotoksin yang bertanggung jawab dalam proses penyerapan membrane eritrosit atau proses hemolisis sel darah. Gen yang mengkode hemolysin ini dilaporkan ditemukan pada beberapa spesies bakteri yang termasuk genus vibrio (Conejero $\&$ Hedreyda, 2004). Bakteri vibrio patogen yang memiliki gen hemolysin diketahui dapat menyebabkan terjadinya lysis pada sel darah inang.

Identifikasi gen penyandi sifat virulensi juga telah dilakukan dengan menggunakan primer tox $R$ dengan suhu annealing $57^{\circ} \mathrm{C}$ dengan hasil terlihat bahwa isolat No 1, 2, 3, $672,673,168$, dan 170 terdeteksi memiliki gen toxR. Namun gen target yang berhasil

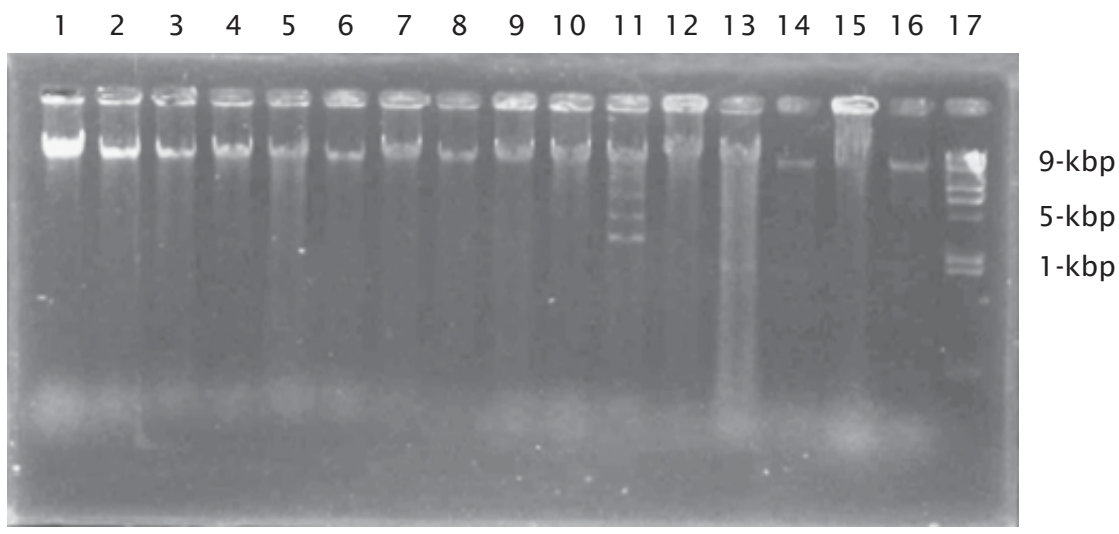

Gambar 1. Hasil isolasi genom dari 16 bakteri uji. Lajur 1-16 masing-masing genom isolat bakteri Vibrio spp. kode 109, 110, 111, 112, 114, 115, $116,119,120,128,130,133,137,139,144,145$. Lajur 17 adalah 1-kbp DNA Ladder

Figure 1. Bacteria genome extraction profile from 16 Vibrio spp. isolates. Lanes 1-16, genome from bacteria isolate number 109, 110,111 , $112,114,115,116,119,120,128,130,133,137,139,144,145$ respectively. Lane 17 contains 1 -kbp DNA Ladder 

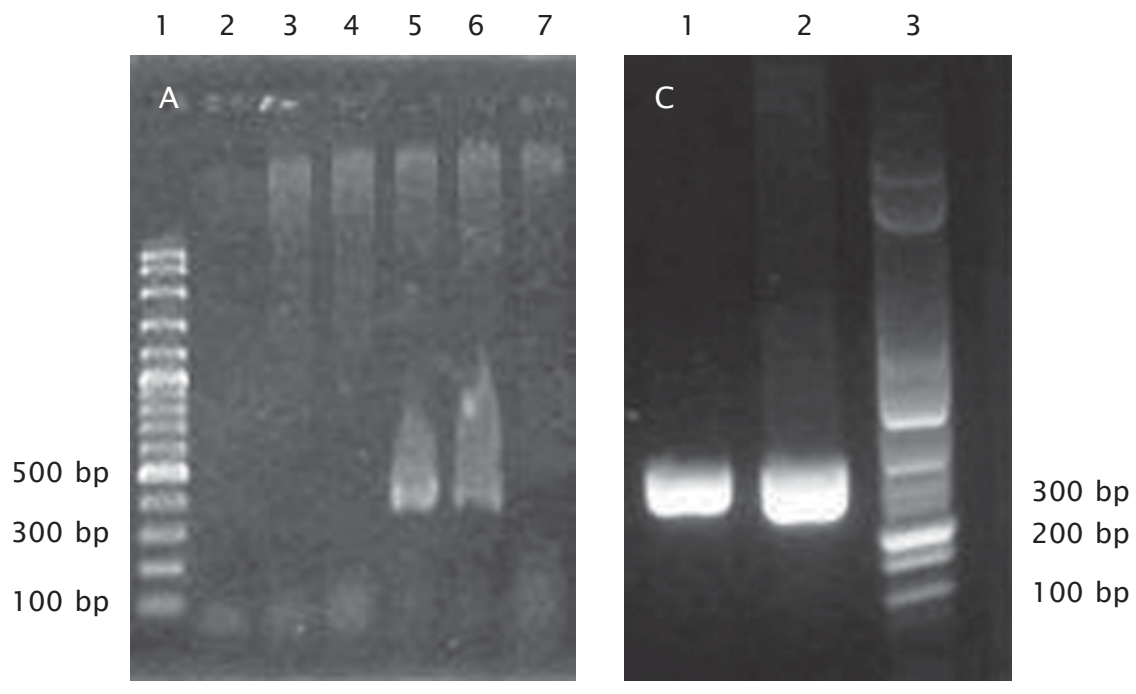

$\begin{array}{lllllllllllllllll}1 & 2 & 3 & 4 & 5 & 6 & 7 & 8 & 9 & 10 & 11 & 12 & 13 & 14 & 15 & 16\end{array}$

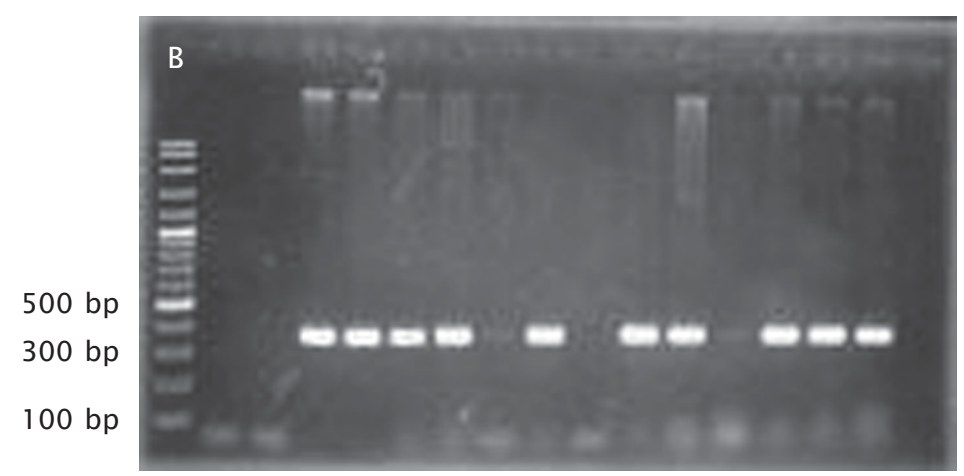

Gambar 2a dan 2b. Hasil PCR untuk primer spesifik A2 dan B3 GyrB dan DNA templat dari 23 isolat bakteri Vibrio spp. (a) Lajur 2-7 masingmasing templat DNA dari isolat kode 1, 2, 3, 109, 120 dan 168. Lajur 1 adalah 100-bp DNA ladder. (b) Lajur 2-16 masing-masing templat DNA dari isolat kode $110,111,5584$, $5585,154,159,671,672,675,676,128,130,133,137$ dan 139. Lajur 1 adalah 100-bp DNA ladder. (c) Lajur 1 DNA templat dari isolate kode 275 , lajur 2 isolat 276 . Lajur 3 adalah 100-bp DNA ladder

Figure 2a and 2b. PCR profiles using GyrB A2 and B3 specific primer and DNA templates from 23 Vibrio spp. isolates. (a) Lanes 2-7 DNA templates from isolate 1, 2, 3, 109, 120 and 168 respectively. Lane 1 contains the 100-bp DNA ladder. (b) Lanes 2-16, DNA templates from isolate 110,111, 5584, $5585,154,159,671,672,675,676,128,130,133,137$ and 139 respectively. Lane 1 contains the 100-bp DNA ladder. (c) Lane 1 and 2 DNA template from isolate 275 and 276 respectively. Lane 3 contains the 100-bp DNA ladder 

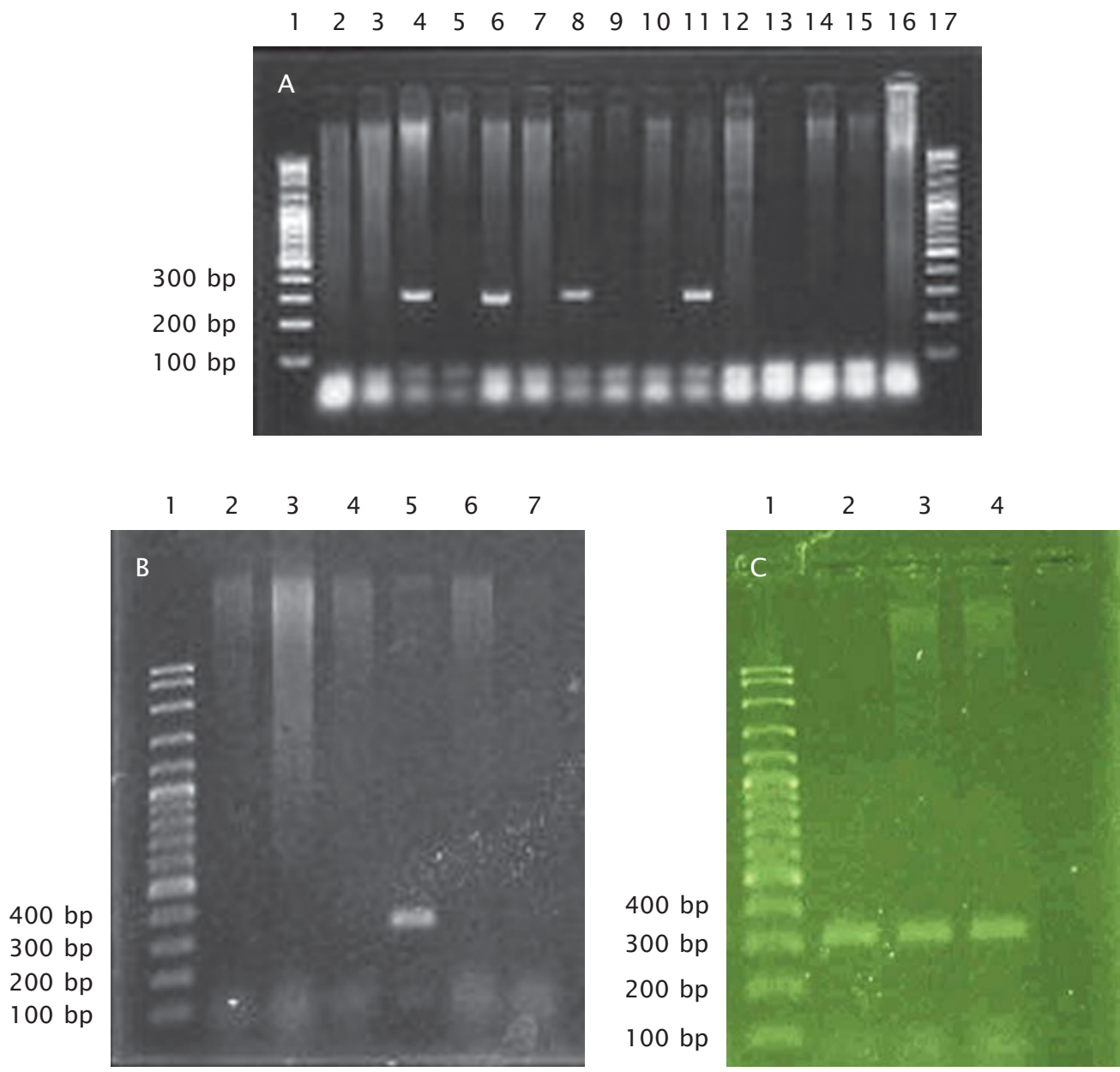

Gambar 3a, 3b, dan 3c. Hasil PCR untuk primer spesifik VHF1 dan VhhemoR hemolysin gene DNA templat dari 24 isolat bakteri Vibrio spp. (a) Lajur 2-16 masingmasing template DNA dari isolate bakteri kode $110,111,5584,5585$, $154,159,671,672,675,676,128,130,133,137$ dan139. Lajur 1 dan 17 adalah 100-bp DNA ladder. (b) Lajur 2- 7 masing-masing template DNA dari isolate bakteri kode 109, 275, 276, 120, 5582, 168 dan 170. Lajur 1 adalah 100-bp DNA ladder. (c) Lajur 2-4 masingmasing template DNA dari isolate bakteri kode 1, 2 dan 3. Lajur 1 adalah 100-bp DNA ladder

Figure $3 a, 3 b$, and $3 c . \quad P C R$ profiles using specific primer VHF1 and VhhemoR hemolysin gene and DNA templates from 24 Vibrio spp. isolates. (a) Lanes 2-16 DNA templates from isolate 110, 111 , 5584, 5585, 154, 159, $671,672,675,676,128,130,133,137$ and 139 respectively. Lane 1 and 17 contain the 100-bp DNA ladder. (b) Lanes 2-7 DNA templates from isolate 109, 275, 276, 5582, 168 and 170 respectively. Lane 1 contains the 100-bp DNA ladder. (c) Lanes 2-4 DNA templates from isolate 1, 2 and 3 respectively. Lane 1 contains the 100bp DNA ladder 

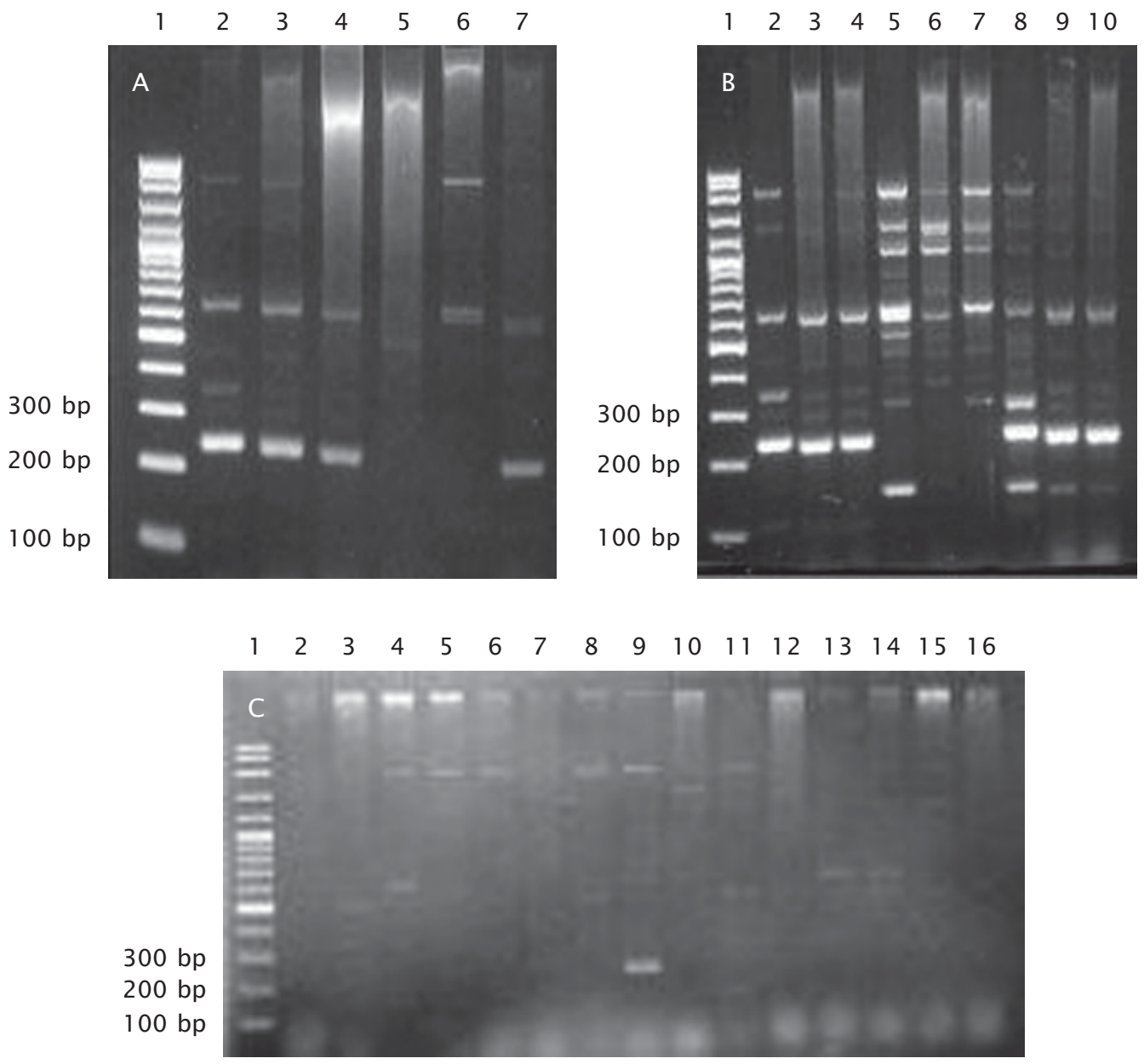

Gambar 4a, 4b, dan 4c. Hasil PCR untuk primer spesifik toxRF1 dan toxRR1 gene DNA templat dari 24 isolat bakteri Vibrio spp. (a) Lajur 2- 7 masing-masing template DNA dari isolate bakteri kode 1, 2, 3, 111,5582 dan 168. Lajur 1 adalah 100-bp DNA ladder.(b) Lajur 2-10 masing-masing template DNA dari isolate bakteri kode 1, 2, 3, 5582, 109, 120, 673, 168 dan 170. Lajur 1 adalah 100-bp DNA ladder. (c) Lajur 2-16 masing-masing template DNA dari isolate bakteri kode $110,111,5584,5585,154$, $159,671,672,675,676,128,130,133,137$ dan139. Lajur 1 adalah 100-bp DNA ladder

Figure $4 a, 4 b$, and $4 c . \quad P C R$ profiles using specific primer toxRF1 dan toxRR1 gene and DNA templates from 24 Vibrio spp. isolates. (a) Lanes 2-7 DNA templates from isolate 1, 2, 3, 111,5582 and 168 respectively. Lane 1 contains the 100-bp DNA ladder. (b) Lanes 2-10 DNA templates from isolate $1,2,3,5582,109,120,673,168$, and 170 respectively. Lane 1 contains the 100-bp DNA ladder. (c) Lanes 2-4 DNA templates from isolate 110, $111,5584,5585,154,159,671,672,675,676,128$, $130,133,137$, and 139 respectively. Lane 1 contains the 100-bp DNA ladder 


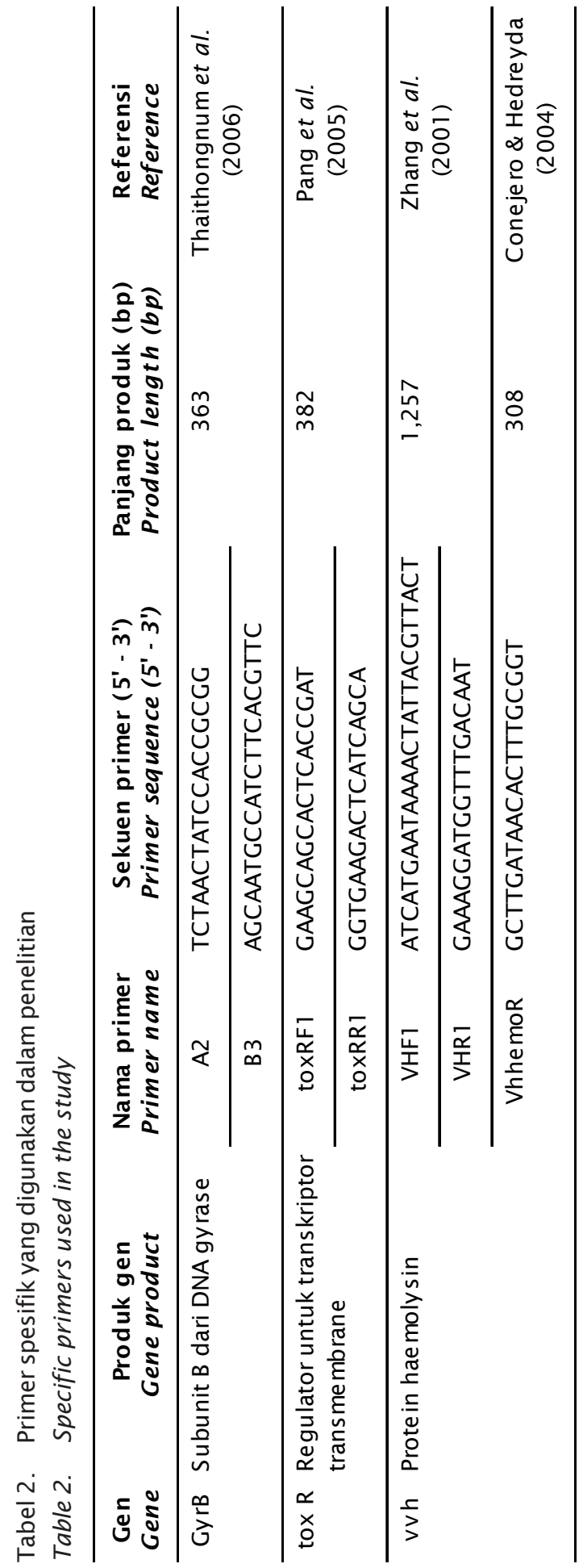


teramplifikasi berada pada panjang basa 240$260 \mathrm{bp}$. Berbeda dengan literatur rujukan yg panjang produk PCR untuk gen toxR sekitar 300 bp (Gambar 4a, 4b, dan 4c). Gen toxR pertama kali ditemukan pada bakteri $V$. cholerae sebagai regulator positif transkripsional dari gen ctx yang mengkode toksin pada Vibrio cholera (Pang et al., 2005; Marlina, 2009). Kemudian gen ini ditemukan juga pada $V$. parahaemolyticus. Gen toxR secara spesifik mengkode protein transmembran yang memegang peranan penting pada regulasi gen toksin ctx dan beberapa gen-gen toksin lainnya. Gen toxR akan mengaktifkan gen-gen lainnya untuk menghasilkan produksi toksin yang berupa hemolisin atau toksin lainnya. toksin inilah yang menjadi senjata utama pada proses patogenisitas bakteri.

Keberadaan gen-gen virulen pada beberapa isolate bakteri mengindikasikan bahwa isolate bakteri tersebut memiliki potensi untuk menjadi patogen pada kondisi ling- kungan yang mendukung. Gen toxR (Pang et al., 2005) mengendalikan expresi beberapa enzim yang berperan dalam proses pelepasan toksin baik eksotoksin maupun endotoksin. Salah satu eksotoksin yang cukup berperan dalam proses patogenesis bakteri adalah hemolysin (Conejero \& Hedreyda, 2004). Gen spesifik GyrB walaupun terdeteksi pada hampir semua isolat bakteri namun terdapat perbedaan struktur dan susunan basa dari DNA penyusunnya. Gen GyrB pada umumnya menjadi target serangan antibiotik untuk melumpuhkan bakteri patogen. Jika gen GyrB dirusak maka proses amplifikasi gen-gen virulen yang dikendalikan oleh enzim gyrase tidak akan dapat berlangsung.

Dari uji dengan menggunakan primer-primer spesifik tersebut terlihat bahwa gen virulen yang menentukan sifat patogen dari bakteri berpendar ini tersebar pada hampir semua isolat bakteri (Tabel 3). Dari Tabel 3 dapat dilihat bahwa pada satu isolat bakteri terdeteksi tidak

Tabel 3. Isolat bakteri yang memiliki gen virulen

Table 3. Bacteria isolates that have virulence gene

\begin{tabular}{|c|c|c|c|c|}
\hline \multirow{2}{*}{$\begin{array}{l}\text { Kode bakteri } \\
\text { Bacteria code }\end{array}$} & \multirow{2}{*}{$\begin{array}{c}\text { Asal } \\
\text { Source }\end{array}$} & \multicolumn{3}{|c|}{$\begin{array}{l}\text { Gen-gen virulen } \\
\text { Virulence gene }\end{array}$} \\
\hline & & Tox-R & Vhh & $G y r-B$ \\
\hline 1 & Banyuwangi & $\checkmark$ & $\checkmark$ & \\
\hline 2 & Bali & $\checkmark$ & $\checkmark$ & \\
\hline 3 & Bali & $\checkmark$ & $\checkmark$ & \\
\hline 5582 & Maros & & $\checkmark$ & $\checkmark$ \\
\hline 5584 & Maros & & $\checkmark$ & $\checkmark$ \\
\hline 5585 & Maros & & & $\checkmark$ \\
\hline 109 & Maros & & & $\checkmark$ \\
\hline 120 & Maros & & & $\checkmark$ \\
\hline 128 & Maros & & & $\checkmark$ \\
\hline 133 & Maros & & & $\checkmark$ \\
\hline 137 & Maros & & & $\checkmark$ \\
\hline 139 & Maros & & & $\checkmark$ \\
\hline 154 & Maros & & $\checkmark$ & $\checkmark$ \\
\hline 159 & Maros & & & $\checkmark$ \\
\hline 671 & Maros & & $\checkmark$ & \\
\hline 672 & Maros & $\checkmark$ & & $\checkmark$ \\
\hline 673 & Maros & $\checkmark$ & & \\
\hline 676 & Maros & & $\checkmark$ & $\checkmark$ \\
\hline 168 & Takalar & $\checkmark$ & & \\
\hline 170 & Takalar & $\checkmark$ & & \\
\hline
\end{tabular}


hanya satu gen penyandi sifat virulensi, misalnya: isolat 1, 2, dan 3 memiliki gen tox $R$ dan Vhh namun tidak memiliki gen GyrB. Isolat bakteri 5582, 5584 dan 154 terdeteksi memiliki dua gen penyandi sifat virulensi yaitu GyrB dan Vhh (hemolysin). Namun adapula isolat bakeri yang terdeteksi hanya memiliki satu gen penyandi sifat virulensi seperti isolat 109 dan 120 yang hanya memiliki gen GyrB sedang isolat 154, 671, 676, dan 5584 hanya memiliki gen Vhh.

Seperti diketahui bakteri Vibrio sp. yang merupakan bakteri patogen oportunistik dapat berubah sifat dari saprofit menjadi patogen pada kondisi lingkungan dan kepadatan bakteri tertentu. Oleh karena itu perlu dilakukan deteksi dini untuk mengidentifikasi keberadaan bakteri ini pada lingkungan budidaya.

\section{KESIMPULAN}

Dari 35 isolat yang diisolasi, dari berbagai daerah (Banyuwangi, Bali, Maros, Takalar, dan Pinrang) 20 isolat terdeteksi memiliki gen penyandi sifat virulensi, di mana 8 di antaranya terdeteksi memiliki 2 gen penyandi sifat virulensi. Patogenisitas dari bakteri Vibrio sp. dapat dipengaruhi dari keberadaan gen-gen penyandi sifat virulensi pada susunan DNAnya.

\section{DAFTAR ACUAN}

Alsina, M. \& Blanch, A.R. 1994. A Set of keys for biochemichal identification of environmental Vibrio species. J. Applied Bacteriology, (76): 79-85.

Austin, B. 1991. Methods in Aquatic Bacteriology. John Wiley and Sons. Chichester. New York. Brisbane. Toronto. Singapore, 425 pp.

Austin, B. \& Austin, D.A. 1993. Bacterial Fish Pathogens. Disease in Farmed and Wild Fish. Second Edition. New York. London. Toronto. Sydney. Tokyo. Singapore, $384 \mathrm{pp}$.

Austin,B. \& Zhang, X.-H. 2006. Vibrio harveyi: a significant pathogen of marine vertebrates and invertebrates. Lett. Appl. Microbiol. 43: 119-124.

Baumann, P., Furniss, A.L., \& Lee, J.V. 1994. Facultative anaerobic gram negative rods. In J.G. Holt, N.R. Krieg, P.H.A. Sneath, J.T. Staley, and S.T. Wilkins (Eds.), Bergey's Manual of Determinative Bacteriology. Ninth Edition. The William and Wilkins, Baltimore, Maryland, USA, p. 175-289.
Ben Haim, Y., Thompson, F.L., Thompson, C.C., Cnockaert, M.C., Hoste, B., Swings, J., \& Rosenberg, E. 2003. Vibrio coralliilyticus sp. nov., a temperature-dependent pathogen of the coral Pocillopora damicornis. Int J Syst Evol Microbiol, 53: 309-315.

Benson, H.J. 1985. Microbiological Applications: A Laboratory Manual in General Microbiology. Fourth Edition. Wm. C. Brown Publishers. Dubuque, lowa, $450 \mathrm{pp}$.

Cano-Gomez, A., Bourne, D.G., Hall, M.R., Owens, L., \& Hoj, L. 2009. Molecular identification, typing and tracking of Vibrio harveyi in aquaculture systems: Current methods and future prospects. Aquaculture, 287: 1-10.

Conejero, M.J.U. \& Hedreyda, C.T. 2004. PCR detection of hemolysin (vhh) gene in Vibrio harveyi. J. Gen. Appl. Microbiol., 50: 137142.

Farmer, J.J. \& Hickman-Brenner, F.W. 1992. The genera Vibrio and Photobacterium. In The Prokaryotes-a Handbook on the Biology of Bacteria: Ecophysiology, Isolation, Identification, Applications, Edited by A. Balows. New York: Springer, p. 2,952-3,01 1.

Karunasagar, I., Pai, R., Malathi, G.R., \& Karunasagar, I. 1994. Mass mortality of Penaeus monodon larvae due to antibioticresistant Vibrio harveyi infection. Aquaculture, 128: 203-209.

Kita-Tsukamoto, K., Oyaizu, H., Nanba, K., \& Simidu, U., 1993. Phylogenetic relationships of marine bacteria, mainly members of the family Vibrionaceae, determined on the basis of $16 \mathrm{~S}$ rRNAsequences. Int. J. Syst. Bacteriol., 43: 8-19.

Lavilla-Pitogo, C.R., Baticados, M.C.L., CruzLacierda, E.R., \& Pena, L.D. 1990. Occurrence of luminous bacterial disease of Penaeus monodon larvae in the Philippines. Aquaculture, 91: 1-13.

Lavilla-Pitogo, C.R., Leano, E.M., \& Paner, M.G. 1998. Mortalities of pond-cultured juvenile shrimp, Penaeus monodon, associated with dominance of luminescent vibrios in the rearing environment. Aquaculture, 164: 337-349.

Leano, E.M., Lavilla-Pitogo, C.R., \& Paner, M.G. 1998. Bacterial flora in the hepatopancreas of pond-reared Penaeus monodon juveniles with luminous vibriosis Aquaculture Department, Southeast Asian Fisheries Development Center, Tigbauan, 5021 Iloilo, Philippines. Aquaculture, 164-1998, p. 367-374. 
Marlina. 2009. Identifikasi Bakteri Vibrio Parahaemolyticus dengan Metode Biolog dan Deteksi Gen ToxRnya secara PCR. Jurnal Sains dan Teknologi Farmasi, Vol. 13, No. 1.

Muir, P. 1996a. Media Used in Vibrio and Photobacterium Identification. Department of Microbiology, Biomedical and Tropical Veterinary Sciences. James Cook University of North Queensland. Australia, $7 \mathrm{pp}$.

Muir, P. 1996b. Identification of Vibrio and Pseudomonas Bacteria. Department of Microbiology, Biomedical and Tropical Veterinary Sciences. James Cook University of North Queensland. Australia, $6 \mathrm{pp}$.

Pang, L., Zhang, X.H., Zhong, Y., Chen, J., Li, Y., \& Austin, B. 2005. Identification of Vibrio harveyi using PCR amplification of the tox $\mathrm{R}$ gene. Lett. Appl. Microbiol., 43: 249-255.

Thaithongnum, S., Ratanama, R., Weeradechapol, K., Sukhoom, A., \& Vuddhakul, V. 2006. Detection of Vibrio harveyi in shrimp postlavae and hatchery tank water by the most probable number technique with PCR, Aquaculture, 261: 19.

Yang, Y.K., Yeh, L.P., Cao, Y.H., Baumann, L., Baumann, P., Tang, J.E., \& Beaman, B. 1983. Characterization of marine luminous bacteria isolated off the coast of China and description of Vibrio orientalis sp. nov. Curr Microbiol., 8: 95-100. http:// mic.sgmjournals.org 1777 Molecular identification of $V$. harveyi-related isolates. 